\title{
Secondary Torsion of
} Vermiform Appendix with Mucinous Cystadenoma

\author{
Maki Kitagawa ${ }^{a}$ Tatsuya Kotani $^{\mathrm{a}}$ Takeshi Yamano \\ Hideaki Tsurudome $^{a}$ Tomoya Hatakeyama $^{a}$ \\ Yoshiaki Kuriu $^{a}$ Hiroshi Nishia $^{\mathrm{a}}$ Masaharu Yabe ${ }^{\mathrm{a}}$
}

Departments of a Surgery and ${ }^{b}$ Pathology, Saiseikai Kyoto Hospital, Nagaokakyo, Kyoto, Japan

\section{Key Words}

Torsion · Appendix · Mucinous cystadenoma

\begin{abstract}
Torsion of the vermiform appendix is a rare disorder, which causes abdominal symptoms indistinguishable from acute appendicitis. We report a case (a 34-year-old male) of secondary torsion of the vermiform appendix with mucinous cystadenoma. This case was characterized by mild inflammatory responses, pentazocine-resistant abdominal pain, and appendiceal tumor, which was not enhanced by the contrast medium on computed tomography presumably because of reduced blood flow by the torsion. These findings may be helpful for the preoperative diagnosis of secondary appendiceal torsion.
\end{abstract}

\section{Introduction}

The vermiform appendix is a blind ended gastrointestinal tract, which is connected to the cecum. It averages $6.5 \mathrm{~cm}$ (ranging from 1 to $20 \mathrm{~cm}$ ) in length. The longest appendix ever reported measured $23.5 \mathrm{~cm}$ in length. Diseases of the appendix are the most common causes of acute abdomen. Among them, torsion of the vermiform appendix is a rare disorder, which causes abdominal symptoms indistinguishable from acute appendicitis, the most common disorder of the appendix. In 1918, Payne et al. reported the first case of torsion of the appendix [1]. Since then, more than thirty cases have been described in the English language literature along with several cases in the non-English language literature (table 1) [1-13]. Torsion of the appendix may occur at any age (mean 23 years; range 360 years). Fourteen cases in children and seventeen cases in adults are reported. In children (mean 9.1 years; range 3-18 years), eleven cases are male and three cases are female. In adults, seven cases are male and ten cases are female. Primary and secondary 
torsion are recognized in the appendiceal torsion. Twenty-five among thirty-two cases are found to be primary torsion. In primary torsion, specimen examination shows secondary ischemic or necrotic change and luminal dilatation distal to the torsion site without any primary lesion. Secondary torsion caused by appendiceal abnormality is much rarer. Only 6 cases (one cystadenoma, three simple mucoceles, one fecalith impaction and one malformation) have been reported to date. Here, we report a case of secondary torsion of the vermiform appendix with mucinous cystadenoma, and review the literature on appendiceal torsion.

\section{Case Report}

A 34-year-old male complained of periumbilical abdominal pain continuing for two days. The pain persisted despite administration of pentazocine. There was no significant previous medical history. On physical examination, his body temperature was $36.7^{\circ} \mathrm{C}$, pulse 78 beats $/ \mathrm{min}$, and blood pressure $110 / 70$ $\mathrm{mm} \mathrm{Hg}$. Bowel sounds were diminished. There were tenderness and rebound tenderness in the right lower quadrant area with muscular guarding. Peripheral blood examination showed a white blood cell (WBC) count of $8,600 / \mathrm{mm}^{3}$ (78\% neutrophils, $15 \%$ lymphocytes, and $7 \%$ monocytes) and C-reactive protein (CRP) of $4.35 \mathrm{mg} / \mathrm{dl}$. Hemoglobin and hematocrit values were $14.6 \mathrm{~g} / \mathrm{dl}$ and $44.9 \%$, respectively. Carcinoembryonic antigen $(1.5 \mathrm{ng} / \mathrm{ml})$ and serum electrolyte levels were within normal limits [14]. Abdominal X-ray examination revealed small-intestinal dilatation with air-fluid level. Abdominal computed tomography (CT) examination suggested a fluid-filled cyst originating in the vermiform appendix (fig. $1 \mathrm{a}-\mathrm{c})$. The cyst wall was not enhanced by the contrast medium. This finding contrasted well with that in a case of acute appendicitis caused by fecalith, in which thickened appendiceal wall was enhanced by the contrast medium (fig. 1i). After $6 \mathrm{~h}$, peripheral blood was reexamined, giving a WBC count of $8,100 / \mathrm{mm}^{3}$ and CRP of $4.42 \mathrm{mg} / \mathrm{dl}$. Laparotomy was done on the suspected diagnosis of appendiceal tumor, which may be complicated by inflammation. Through a pararectus incision, a small amount of serosanguinous fluid and a deep purple cystic tumor came out. The cytological examination of the ascites revealed no malignancy. The tumor was $10 \mathrm{~cm}$ in length and $4 \mathrm{~cm}$ in diameter, and originated in the appendix. It was twisted $180^{\circ}$ in a clockwise direction with ischemic change (fig. 1d). The abdominal pain was abruptly relieved before the laparotomy presumably because of spontaneous relief of the torsion as indicated by mild rotation $\left(180^{\circ}\right)$ of the tumor observed at laparotomy. A simple appendectomy was performed. Histological examination of the specimen revealed that the proximal 1 $\mathrm{cm}$ was normal appendix and the distal $10 \mathrm{~cm}$ was a monocystic mucinous cystadenoma, which was filled with yellow-colored degenerated mucin (fig. 1e, f). The inner surface was lined by pseudostratified columnar epithelium with slight nuclear atypia. Subepithelial tissue showed dense fibrosis and mild inflammation (fig. 1g, h). Subserosal adipose tissue showed some hemorrhage and necrosis, and there was perivascular inflammatory cell infiltration. The histological findings were compatible with the ischemic and necrotic changes caused by the torsion. Postoperative recovery was uneventful, and postoperative total colonoscopy revealed no abnormality in the cecum.

\section{Discussion}

Acute appendicitis is the most common disorder in patients complaining of right lower abdominal pain. By contrast, torsion of the vermiform appendix is a rare disorder. Primary and secondary torsion of the vermiform appendix are recognized. Primary torsion appears to be often associated with long appendix. Secondary torsion is reported to be associated with cystadenoma, mucocele, fecalith impaction, and malformation of the appendix (table 1). Here, we report a case of secondary torsion of the appendix, which is associated with mucinous cystadenoma. Cystadenoma of the appendix is also a rare condition, and is usually diagnosed intraoperatively or postoperatively on the pathology report. To our knowledge, this is the second case of secondary torsion of the vermiform 
appendix associated with appendiceal cystadenoma. This case showed abdominal pain indistinguishable from acute appendicitis, and was characterized by mild inflammatory responses on the basis of the values of a WBC count and CRP, pentazocine-resistant abdominal pain, and appendiceal tumor, which was not enhanced by the contrast medium on CT presumably because of impaired or reduced blood flow by the torsion. Mild inflammatory responses $[3,5,7-11,13]$ and pentazocine-resistant abdominal pain [3] have been reported in some cases of appendiceal torsion. In this case, besides mild inflammatory responses and pentazocine-resistant abdominal pain, CT examination was helpful for the preoperative diagnosis of secondary appendiceal torsion and appendiceal tumor complicated by inflammatory events including torsion. 


\begin{tabular}{c|l|l|l}
$\begin{array}{c}\text { CaseReportsin } \\
\text { Gastroenterology }\end{array}$ & $\begin{array}{l}\text { Case Rep Gastroenterol 2007;1:32-37 } \\
\text { D0I: 10.1159/000104679 }\end{array}$ & Published online: June 26, 2007 & $\begin{array}{l}\text { @ 2007 S. Karger AG, Basel } \\
\text { ISSN 1662-0631 } \\
\text { www.karger.com/crg }\end{array}$ \\
\hline
\end{tabular}

Table 1. Cases of appendiceal torsion reported in the English literature

\begin{tabular}{|c|c|c|c|c|c|c|}
\hline Authors & Year & Age & Sex & $\begin{array}{l}\text { Degree/direction } \\
\text { of rotation }\end{array}$ & $\begin{array}{l}\text { Length of } \\
\text { appendix, cm }\end{array}$ & Etiology or complication \\
\hline Payne & 1918 & 37 & $\mathrm{~F}$ & $1,080 /-$ & 7 & Fecalith impaction* \\
\hline Bevers & 1920 & 35 & $\mathrm{~F}$ & $720 /-$ & 7.6 & $\mathrm{UD}$ \\
\hline Mcfadden & 1926 & UD & M & $180 /-$ & 12.7 & UD \\
\hline Flatley & 1936 & 22 & $\mathrm{~F}$ & $900 /-$ & 10.8 & UD \\
\hline Dickson & 1953 & 60 & $\mathrm{~F}$ & $720 /-$ & 11.5 & Simple mucocele* \\
\hline Carter & 1959 & 8 & $\mathrm{~F}$ & $>360 / \mathrm{AC}$ & - & $\mathrm{UD}^{1}$ \\
\hline King-Pan & 1965 & 18 & $\mathrm{~F}$ & $-1-$ & 10 & Simple mucocele* \\
\hline \multirow[t]{2}{*}{ Ghent } & 1966 & 21 & M & $450 / \mathrm{AC}$ & - & Primary \\
\hline & & 12 & M & $>360 / \mathrm{C}$ & 7 & Primary \\
\hline Killam & 1969 & 47 & M & $-1-$ & - & Mesoappendiceal lipoma \\
\hline De Bruin & 1969 & 28 & $\mathrm{~F}$ & $360 /-$ & 10.5 & UD \\
\hline Legg & 1973 & 29 & M & $360 /-$ & 10 & UD \\
\hline \multirow[t]{2}{*}{ Finch } & 1974 & 38 & $\mathrm{~F}$ & $360 /-$ & - & UD \\
\hline & & 12 & M & $270 / \mathrm{AC}$ & - & UD \\
\hline Won & 1977 & 35 & M & $-1-$ & 12 & UD \\
\hline William & 1983 & 4 & M & $270 / \mathrm{AC}$ & - & UD \\
\hline \multirow[t]{3}{*}{ Dewan } & 1986 & 3 & M & 720/AC & - & UD \\
\hline & & 6 & $\mathrm{~F}$ & $1080 / \mathrm{C}$ & 7 & UD \\
\hline & & 16 & M & $-1-$ & - & UD \\
\hline Waters & 1986 & 3 & $\mathrm{M}$ & $720 /-$ & - & UD \\
\hline Abu Zidan & 1992 & 32 & $\mathrm{~F}$, pregnant & $-/ \mathrm{C}$ & 5.9 & Mucocele $^{*}$ \\
\hline Merret & 1992 & 14 & $\mathrm{M}$ & $720 / \mathrm{AC}$ & 14 & Normal appendix \\
\hline Fernando & 1995 & 6 & M & $>360 / \mathrm{AC}$ & 13.5 & UD \\
\hline Petersen & 1998 & 44 & M & $540 /-$ & 5.5 & UD \\
\hline Uroz-Tristan & 1998 & 5 & M & $360 / \mathrm{AC}$ & - & Absent mesoappendix \\
\hline Tzilinis & 2002 & 44 & M & $540 / \mathrm{C}$ & 5.5 & Primary \\
\hline Moten & 2002 & 44 & $\mathrm{~F}$ & $360 / \mathrm{AC}$ & - & Cystadenoma* \\
\hline Oguzkurt & 2004 & 2 & M & $270 / \mathrm{AC}$ & 10 & $\begin{array}{l}\text { Duplicated colon and } \\
\text { appendix* }\end{array}$ \\
\hline Bowling & 2006 & Adult & $\mathrm{F}$ & $-1-$ & 8 & UD \\
\hline Bestman & 2006 & 35 & $\mathrm{~F}$ & $-1-$ & 7.5 & Primary \\
\hline Sarin & 2006 & 9 & M & $270 / \mathrm{C}$ & 8 & Normal appendix \\
\hline Present case & 2007 & 34 & M & $180 / \mathrm{C}$ & 10 & Mucinous cystadenoma* \\
\hline
\end{tabular}




\begin{tabular}{c|l|l|l}
$\begin{array}{c}\text { Case Reportsin } \\
\text { Gastroenterology }\end{array}$ & $\begin{array}{l}\text { Case Rep Gastroenterol 2007;1:32-37 } \\
\text { Dol: 10.1159/000104679 }\end{array}$ & Published online: June 26, 2007 & $\begin{array}{l}\text { I 2007 S. Karger AG, Basel } \\
\text { ISSN 1662-0631 } \\
\text { www.karger.com/crg }\end{array}$ \\
\hline
\end{tabular}

Fig. 1. a-c Enhanced abdominal CT examination showed a cyst originating in the vermiform appendix. The cyst wall was not enhanced by the contrast medium. $\mathbf{d}$ The tumor originated in the appendix and was twisted $180^{\circ}$ in a clockwise direction (arrow). e The resected tumor was $10 \mathrm{~cm}$ in length and $4 \mathrm{~cm}$ in diameter. $\mathbf{f}$ The specimen contained yellow-colored degenerated mucin. $\mathbf{g}$,

h Histological examination. The inner surface was lined by pseudostratified columnar epithelium with slight nuclear atypia. Subepithelial tissue showed dense fibrosis and mild inflammation. Original maginification: $\mathbf{g} \times 20 ; \mathbf{h} \times 200$. i Enhanced abdominal CT examination in a case of acute appendicitis caused by fecalith. Appendiceal lumen distal to fecalith was dilated and the thickened appendiceal wall was enhanced by the contrast medium (arrow).
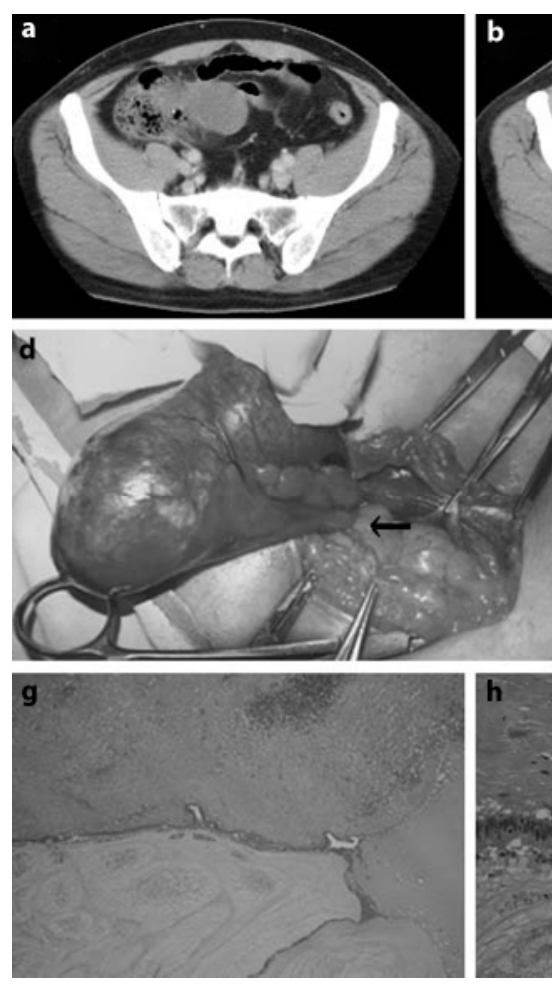
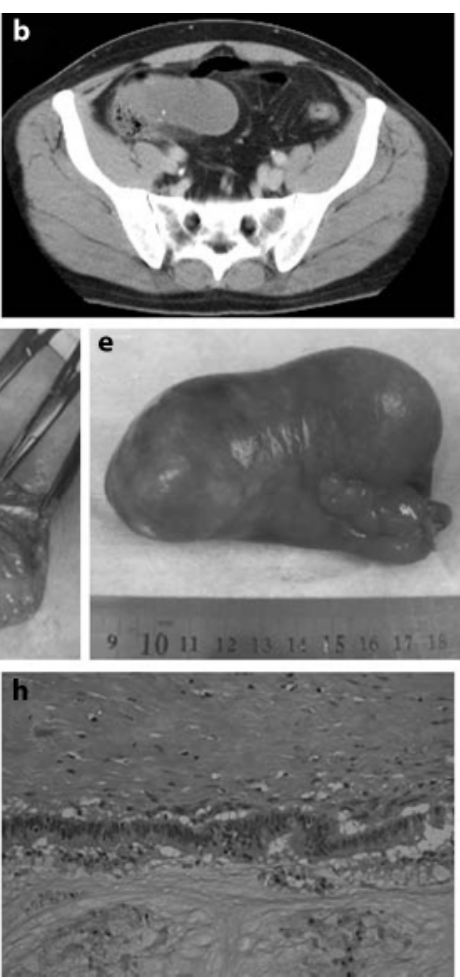
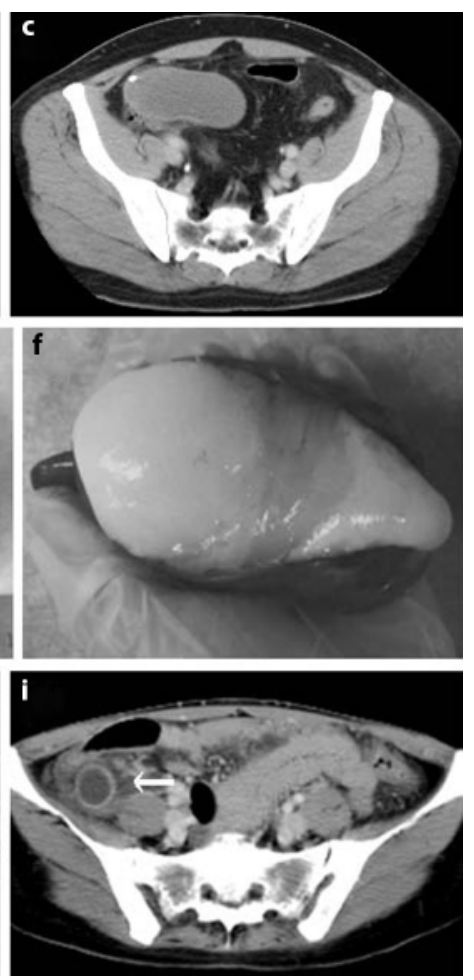


\begin{tabular}{c|l|l|l}
$\begin{array}{c}\text { CaseReportsin } \\
\text { Gastroenterology }\end{array}$ & $\begin{array}{l}\text { Case Rep Gastroenterol 2007;1:32-37 } \\
\text { Dol: 10.1159/000104679 }\end{array}$ & Published online: June 26, 2007 & $\begin{array}{l}\text { @ 2007 S. Karger AG, Basel } \\
\text { ISSN 1662-0631 } \\
\text { www.karger.com/crg }\end{array}$ \\
\hline
\end{tabular}

\section{References}

1 Payne LE: A case of torsion of the appendix. Br J Surg 1918;6:327.

2 Val-Bernal JF, Gonzalez-Vela C, Garijo MF: Primary acute torsion of the vermiform appendix. Pediatr Pathol Lab Med 1996;16:655-661.

3 Tzilinis A, Vahedi MH, Wittenborn WS: Appendiceal torsion in an adult: case report and review of the literature. Curr Surg 2002;59:410-411.

4 Moten AL, Williams RS: Torsion of the appendix. Med J Aust 2002;177:632.

5 Bestman TJ, van Cleemput M, Detournay G: Torsion of the vermiform appendix: a case report. Acta Chir Belg 2006;106:228-229.

6 Oguzkurt P, Oguzkurt L, Kayaselcuk F, Oz S: An unusual cause of acute abdomen: torsion of colonic duplication over a duplicated appendix. Pediatr Surg Int 2004;20:722-723.

7 Uroz-Tristan J, Garcia-Urgelles X, Poenaru D, Avila-Suarez R, ValencianoFuentes B: Torsion of vermiform appendix: value of ultrasonographic findings. Eur J Pediatr Surg 1998;8:376-377.

8 Mazza D, Fabiani P, Casaccia M, Baldini E, Gugenheim J, Mouiel J: A rare laparoscopic diagnosis in acute abdominal pain: torsion of epiploic appendix. Surg Laparosc Endosc 1997;7:456-458.

9 Merrett ND, Lubowski DZ, King DW: Torsion of the vermiform appendix: a case report and review of literature. Aust N Z J Surg 1992;62:981-983.

10 Abu Zidan FM, al-Hilaly MA, al-Atrabi N: Torsion of a mucocele of the appendix in a pregnant woman. Acta Obstet Gynecol Scand 1992;71:140-142.

11 Killam AR: An unusual cause of appendicitis: torsion produced by a mesoappendiceal lipoma. Am Surg 1969;35:648-649.

12 Ghent WR, Carnovale BV: Primary volvulus of the appendix. Can Med Assoc J 1966;95:926-927.

13 King-Pan C: Volvulus complicating mucocele of the appendix. Br J Surg 1965;52:9.

14 Shimizu T, Shimizu M, Kawaguchi K, Yomura W, Ihara Y, Matsumoto T: Mucinous cystadenoma of the appendix with raised serum carcinoembryonic antigen concentration: clinical and pathological features. J Clin Pathol 1997;50:613-614. 